\title{
Chlorogenic acid and kojic acid as anti-hyperpigmentation: in silico study
}

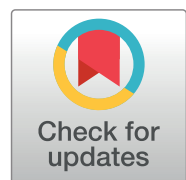

\author{
I Made Agus Yudantara $\mathbb{D}^{*}$, Ni Ketut Nitya Cahyani $\mathbb{D}$, Made Agus Widiana Saputra $\mathbb{D}$, \\ Ni Kadek Diah Parwati Dewi 1
}

Department of Pharmacy, Faculty of Mathematics and Natural Science, Udayana University, Bali 80361, Indonesia

*Corresponding author: Jl. Kampus Bukit Jimbaran, Badung, Bali 80361, Indonesia. Email: agusyudantara13@gmail.com

\begin{abstract}
Hyperpigmentation is a skin problem caused by excessive melanin production due to continuous ultraviolet (UV) radiation. Kojic acid that inhibiting melanin synthesis is a prevalent treatment for hyperpigmentation. This study aims to determine the potential of chlorogenic acid and kojic acid as an anti-hyperpigmentation against tyrosinase using in silico molecular docking. The docking process involved optimizing chlorogenic acid and kojic acid structures, preparing tyrosinase protein (PDB ID: 5M8O), validating the molecular docking method, and docking of chlorogenic acid and kojic acid on tyrosinase. The binding energy of chlorogenic acid and kojic acid were $-4.59 \mathrm{kcal} / \mathrm{mol}$ and $-3.75 \mathrm{kcal} / \mathrm{mol}$, while the binding energy of 0TR native ligand was $-5.02 \mathrm{kcal} / \mathrm{mol}$. The interaction of chlorogenic acid to tyrosinase involved ARG 321 and ARG 374 residues. The results suggest that chlorogenic acid and kojic acid has the potential as anti-hyperpigmentation agents through inhibition of the tyrosinase enzyme.
\end{abstract}

Keywords: anti-hyperpigmentation, chlorogenic acid, kojic acid, molecular docking, tyrosinase

\section{Introduction}

UV radiation exposure can cause hyperpigmentation that results in excessive melanin production [1]. Melanin is responsible for various pigmentation found in animal and human skin, hair, and eyes. Melanin biosynthesis is catalyzed by tyrosinase, an enzyme that plays a role in the formation of skin pigment (melanogenesis). Tyrosinase acts as a catalyst in two different reactions: the hydroxylation of tyrosine to dihydroxy-phenylalanine (L-DOPA) and the oxidation of L-DOPA to DOPAquinone [2].

Tyrosinase activity can be inhibited by tyrosinase inhibitors such as kojic acid, which are developed in the cosmetic and pharmaceutical industries [3]. However, kojic acid has several adverse effects on the skin, such as allergic reactions, skin redness, burning, and itching. Recently, anti-hyperpigmentation agents from natural ingredients have been studied $[4,5]$. Chlorogenic acid (5-caffeoylquinic acid) is a well-known plant phenolic compound found in coffee, apples, and pears [6]. Chlorogenic acid suppresses melanogenesis in B16 melanoma cells incubated with 8-methoxy psoralen (8-MOP). 8-MOP stimulates the expression level of microphthalmia-associated transcription factors (MITF), which stimulates tyrosinase expression [7].

Chlorogenic acid analog consisting of pyridine, pyrimidine motifs, and cyclohexyl ester analog showed strong inhibitory activity against melanin production in B16 melanoma cells on a-MSH stimulation. The study showed that the pyridine and diacyl chlorogenic acid cyclohexyl ester analog had a significantly superior inhibitory potential than kojic acid [8]. Other chlorogenic acid derivatives containing thiazole possess anti-hyperpigmentation activity evaluated through a-MSH-induced melanogenesis in B16 mouse melanoma cells. The result showed a significantly high inhibitory effect with an $\mathrm{IC}_{50}$ of $0.90 \mu \mathrm{M}$. The inhibitory activity was improved by replacing an $\alpha, \beta$ unsaturated carbonyl with a thiazole ring to mitigate poor metabolic stability and bioactivation [9].

However, research on chlorogenic acid inhibiting the tyrosinase enzyme by in silico molecular docking has not been investigated. This method is used to calculate and predict the interaction between the molecule and protein. Therefore, this study aims to determine the potential of chlorogenic acid in inhibiting tyrosinase enzymes by in silico molecular docking.

\section{Methods}

Optimization of chlorogenic acid and kojic acid structures

Chlorogenic acid and kojic acid structures were downloaded from PubChem (https://pubchem.ncbi. nlm.nih.gov/). Austin Model 1 (AM1) semi-empirical 
a

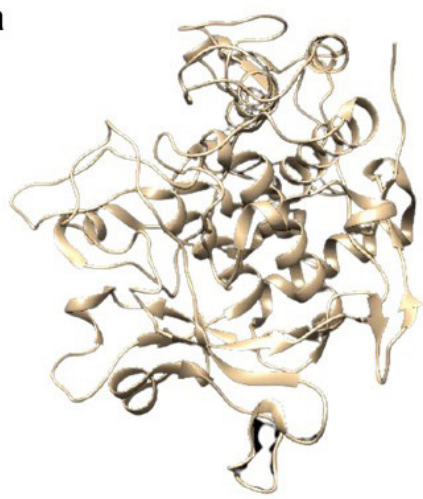

b

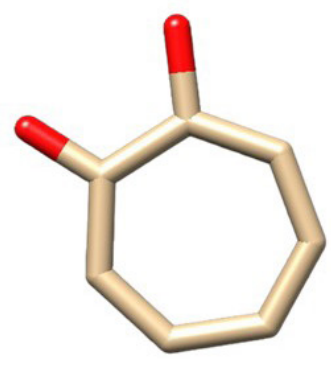

Figure 1. The result of single point calculation and geometry optimization. (a, b) chlorogenic acid, (c, d) kojic acid

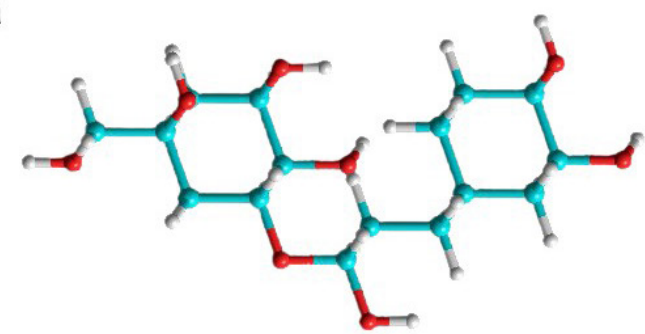

C

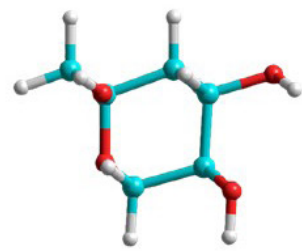

b

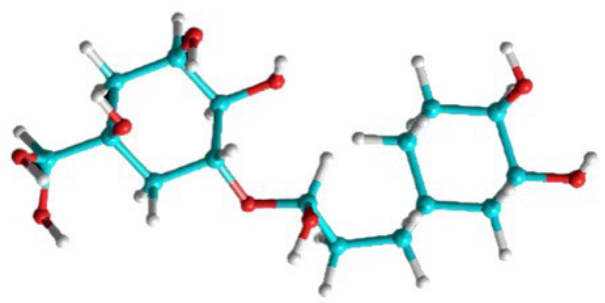

d

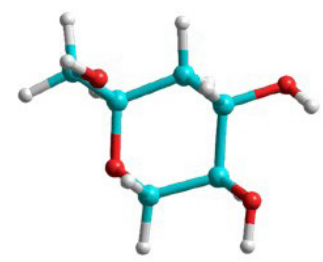

Figure 2. The results of protein preparation. (a) tyrosinase target protein without native ligand, (b) 0TR native ligand

computational method and single-point calculations and geometry optimization were used to optimize both structures by HyperChem 8 .

\section{Preparation tyrosinase target protein}

Tyrosinase (PDB ID: 5M8O) was downloaded from https://www.rcsb.org/structure/5M8O and prepared by separating the protein from 2-hydroxycyclohepta2,4,6-trien-1-one (0TR) (tropolone) native ligand using Chimera 1.10.1 [10].

\section{Molecular docking validation}

Redocking the OTR native ligand was used for validation of the docking procedure using Autodock 4.2. The root mean square deviation (RMSD) value was used for measuring the validity of the procedure (valid if $\leq 3.0 \AA$ ) [11]. The adjusted grid box size ( $\mathrm{x}$ $=40 \AA, \mathrm{y}=40 \AA, \mathrm{z}=40 \AA$ ) and grid center ( $\mathrm{x}=$
$-13.284 \AA, y=2.746 \AA, z=-25.24 \AA$ ) were applied for the validation step.

\section{Docking of chlorogenic acid and kojic acid}

The docking of chlorogenic acid and kojic acid using Autodock 4.2 was performed with grid box size and grid center, same as in validation step. The docking procedure produced the binding energy and interaction of the docked chlorogenic acid and kojic acid to tyrosinase.

\section{Results}

Optimization of chlorogenic acid and kojic acid structures

The single-point calculation and geometry optimization yielded the most stable structure of chlorogenic acid and kojic acid. Chlorogenic acid had a single-point energy calculation of $-4418.89 \mathrm{kcal} /$ 
Table 1. The parameters of validation procedure

\begin{tabular}{|c|c|c|c|c|c|}
\hline Ligand & Conformations & $\begin{array}{l}\text { RMSD } \\
(\AA))\end{array}$ & $\begin{array}{c}\text { Binding energy } \\
\text { (kcal/mol) }\end{array}$ & $\begin{array}{l}\text { Amino acid } \\
\text { residues }\end{array}$ & $\begin{array}{c}\text { Groups in } \\
\text { hydrogen bonds }\end{array}$ \\
\hline \multirow{10}{*}{ OTR } & 1 & 0.80 & -5.02 & HIS 215 & HE2-OA1 \\
\hline & $2^{*}$ & 0.79 & -5.02 & HIS 215 & HE2-OA1 \\
\hline & 3 & 0.82 & -5.03 & HIS 215 & HE2-OA1 \\
\hline & 4 & 0.80 & -5.02 & $\begin{array}{l}\text { HIS } 215 \\
\text { HIS } 192\end{array}$ & $\begin{array}{l}\text { HE2-OA1 } \\
\text { HE2-OA1 }\end{array}$ \\
\hline & 5 & 0.81 & -5.03 & $\begin{array}{l}\text { HIS } 215 \\
\text { HIS } 192\end{array}$ & $\begin{array}{l}\text { HE2-OA1 } \\
\text { HE2-OA1 }\end{array}$ \\
\hline & 6 & 0.81 & -5.02 & $\begin{array}{l}\text { HIS } 215 \\
\text { HIS } 192\end{array}$ & $\begin{array}{l}\text { HE2-OA1 } \\
\text { HE2-OA1 }\end{array}$ \\
\hline & 7 & 0.81 & -5.03 & $\begin{array}{l}\text { HIS } 215 \\
\text { HIS } 192\end{array}$ & $\begin{array}{l}\text { HE2-OA1 } \\
\text { HE2-OA1 }\end{array}$ \\
\hline & 8 & 0.81 & -5.03 & $\begin{array}{l}\text { HIS } 215 \\
\text { HIS } 192\end{array}$ & $\begin{array}{l}\text { HE2-OA1 } \\
\text { HE2-OA1 }\end{array}$ \\
\hline & 9 & 0.81 & -5.03 & $\begin{array}{l}\text { HIS } 215 \\
\text { HIS } 192\end{array}$ & $\begin{array}{l}\text { HE2-OA1 } \\
\text { HE2-OA1 }\end{array}$ \\
\hline & 10 & 0.81 & -5.03 & $\begin{array}{l}\text { HIS } 215 \\
\text { HIS } 192\end{array}$ & $\begin{array}{l}\text { HE2-OA1 } \\
\text { HE2-OA1 }\end{array}$ \\
\hline
\end{tabular}

mol and geometry optimization of $-5333.74 \mathrm{kcal} / \mathrm{mol}$, while the two parameters for kojic acid were -2059.63 $\mathrm{kcal} / \mathrm{mol}$ and $-2091.26 \mathrm{kcal} / \mathrm{mol}$, respectively (Figure 1). Decreasing the energy after optimization indicates that a more stable structure was constructed.

\section{Preparation of tyrosinase target protein}

The preparation of tyrosinase protein included the separation of 0TR native ligand from the protein and removing the solvents. The tyrosinase protein without OTR native ligand and a separate $0 \mathrm{TR}$ native ligand are visualized in Figure 2.

\section{Molecular docking validation}

The validation process by redocking procedure produced ten conformations of OTR native ligand with different RMSD values and binding energies. Conformation 2 was selected with the lowest RMSD value $(0.79 \AA, \leq 3.0 \AA)$ and binding energy of -5.02 $\mathrm{kcal} / \mathrm{mol}$ (Table 1).

\section{Docking of chlorogenic acid and kojic acid}

The docking of chlorogenic acid and kojic acid against tyrosinase produced 10 conformations with various binding energy values. The lowest binding energy of chlorogenic acid and kojic acid was $-4.59 \mathrm{kcal} / \mathrm{mol}$ and $-3.75 \mathrm{kcal} / \mathrm{mol}$, respectively (Table 2 and 3 ).

\section{Interaction analysis}

The 0TR native ligand, chlorogenic acid, and kojic acid are bound to tyrosinase through hydrogen bonds. The $0 \mathrm{TR}$ native ligand interacted to tyrosinase by hydrogen bonding through HIS 215 residue, while chlorogenic acid through ARG 321 and ARG 374 residues. Kojic acid coordinated to tyrosinase by HIS 215, HIS 192, and SER 394 residues (Figure 3).

\section{Discussion}

Chlorogenic acid and kojic acid have the potential as anti-hyperpigmentation agents suggested from their binding energy, which is $-4.59 \mathrm{kcal} / \mathrm{mol}$ and $-3.75 \mathrm{kcal} /$ mol. The binding energy of the $0 \mathrm{TR}$ native ligand was $-5.02 \mathrm{kcal} / \mathrm{mol}$. Chlorogenic acid interacted with tyrosinase through hydrogen bonding with ARG 321 and ARG 374 residues.

In silico molecular docking study of cinnamic acid against tyrosinase (PDB ID: 5M80) resulted in a $-4.59 \mathrm{kcal} / \mathrm{mol}$ energy binding [12]. Other phenolic compounds such as caffeic acid, cinnamic acid, ferulic acid, and p-coumaric acid also showed inhibition of the tyrosinase enzyme. In silico study of these molecules to tyrosinase enzyme (PDB ID: 5I38) with grid coordinates $\mathrm{x}=2.127 \AA, \mathrm{y}=101.824 \AA, \mathrm{z}=25.596$ $\AA$ produced binding energies of $-6.4,-6.1,-5.9$, and $-6.1 \mathrm{kcal} / \mathrm{mol}$ for caffeic acid, cinnamic acid, ferulic acid, and $p$-coumaric acid, respectively [13]. 
a

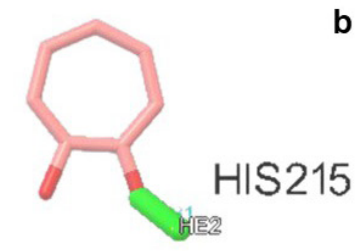

b

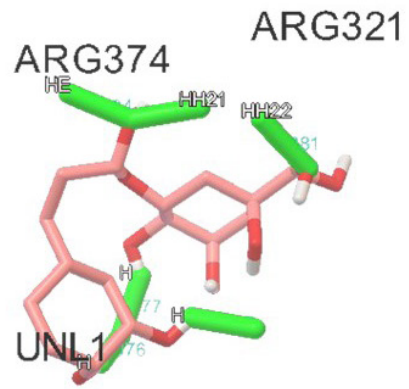

c

HIS215

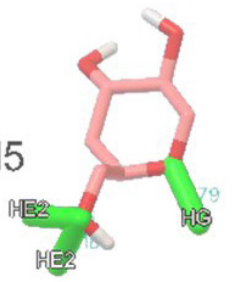

SER39

HIS192

Figure 3. Visualization interaction of docking results on tyrosinase. (a) OTR native ligand, (b) chlorogenic acid, (c) kojic acid

Table 2. The result of molecular docking of chlorogenic acid on tyrosinase

\begin{tabular}{|c|c|c|c|c|}
\hline Ligand & Conformations & $\begin{array}{l}\text { Binding energy } \\
\text { (kcal/mol) }\end{array}$ & $\begin{array}{l}\text { Amino acid } \\
\text { residues }\end{array}$ & $\begin{array}{c}\text { Groups in } \\
\text { hydrogen bonds }\end{array}$ \\
\hline \multirow{10}{*}{ Chlorogenic acid } & 1 & -2.16 & - & - \\
\hline & 2 & -3.22 & TYR 362 & $\mathrm{HH}-\mathrm{O}$ \\
\hline & 3 & -2.99 & TYR 362 & $\mathrm{HH}-\mathrm{O}$ \\
\hline & 4 & -3.79 & SER 394 & $\mathrm{HG}-\mathrm{O}$ \\
\hline & 5 & -3.76 & ARG 374 & HE-O \\
\hline & 6 & -1.65 & TYR 362 & $\mathrm{HH}-\mathrm{O}$ \\
\hline & 7 & -3.67 & - & - \\
\hline & 8 & -4.38 & ARG 374 & $\mathrm{HH} 21-\mathrm{O}$ \\
\hline & 9 & -1.77 & - & - \\
\hline & $10^{*}$ & -4.59 & $\begin{array}{l}\text { ARG } 374 \\
\text { ARG } 321 \\
\text { ARG } 321\end{array}$ & $\begin{array}{c}\mathrm{HE}-\mathrm{O} \\
\mathrm{HH} 21-\mathrm{O} \\
\mathrm{HH} 22-\mathrm{O}\end{array}$ \\
\hline
\end{tabular}

Table 3. The result of molecular docking of kojic acid on tyrosinase

\begin{tabular}{|c|c|c|c|c|}
\hline Ligand & Conformations & $\begin{array}{l}\text { Binding energy } \\
\text { (kcal/mol) }\end{array}$ & $\begin{array}{l}\text { Amino acid } \\
\text { residues }\end{array}$ & $\begin{array}{c}\text { Groups in hydrogen } \\
\text { bonds }\end{array}$ \\
\hline \multirow{10}{*}{ Kojic acid } & 1 & -3.60 & SER 394 & $\mathrm{HG}-\mathrm{O}$ \\
\hline & 2 & -3.21 & $\begin{array}{l}\text { HIS } 192 \\
\text { HIS } 215\end{array}$ & $\begin{array}{l}\text { HE2-O } \\
\text { HE2-O }\end{array}$ \\
\hline & $3^{*}$ & -3.75 & $\begin{array}{l}\text { HIS } 215 \\
\text { SER } 394 \\
\text { HIS } 192\end{array}$ & $\begin{array}{l}\text { HE2-O } \\
\text { HG-O } \\
\text { HE2-O }\end{array}$ \\
\hline & 4 & -3.25 & $\begin{array}{l}\text { HIS } 192 \\
\text { HIS } 215\end{array}$ & $\begin{array}{l}\text { HE2-O } \\
\text { HE2-O }\end{array}$ \\
\hline & 5 & -3.68 & SER 394 & $\mathrm{HG}-\mathrm{O}$ \\
\hline & 6 & -3.14 & $\begin{array}{l}\text { HIS } 192 \\
\text { HIS } 215\end{array}$ & $\begin{array}{l}\text { HE2-O } \\
\text { HE2-O }\end{array}$ \\
\hline & 7 & -3.30 & $\begin{array}{l}\text { HIS } 192 \\
\text { HIS } 215\end{array}$ & $\begin{array}{l}\text { HE2-O } \\
\text { HE2-O }\end{array}$ \\
\hline & 8 & -3.18 & $\begin{array}{l}\text { HIS } 192 \\
\text { HIS } 215\end{array}$ & $\begin{array}{l}\text { HE2-O } \\
\text { HE2-O }\end{array}$ \\
\hline & 9 & -3.28 & $\begin{array}{l}\text { HIS } 192 \\
\text { HIS } 215\end{array}$ & $\begin{array}{l}\text { HE2-O } \\
\text { HE2-O }\end{array}$ \\
\hline & 10 & -3.13 & $\begin{array}{l}\text { HIS } 192 \\
\text { HIS } 215\end{array}$ & $\begin{array}{l}\text { HE2-O } \\
\text { HE2-O }\end{array}$ \\
\hline
\end{tabular}


The in vitro anti-hyperpigmentation study of chlorogenic acid was evaluated by measuring the impacts of this compound on the 8-MOP-treated B16 melanoma cells. Chlorogenic acid suppressed the melanogenesis in B16 melanoma cells by inhibiting enzymatic oxidation of a diphenol, especially in B16 melanoma cells activated by 8-MOP. Chlorogenic acid was involved in melanogenesis and affected tyrosinase activity by suppressing cell proliferation accelerated by 8-MOP [7].

Another phenolic compound, such as gallic acid, also has tyrosinase inhibitory activity in vitro. Tyrosinase inhibition activity was determined using the modified dopachrome method with L-DOPA as the substrate. The inhibition of tyrosinase by this compound is possibly due to the ability of hydroxyl groups to lower the enzymatic activity by hydrogen bonding formation at the active site [14]. These findings support the evidence that chlorogenic acid has anti-hyperpigmentation activity by inhibiting tyrosinase, which could be helpful in cosmetic and pharmaceutical preparations.

\section{Conclusion}

Chlorogenic acid has potential as antihyperpigmentation agent in silico through inhibition of the tyrosinase enzyme and promising to be developed as a tyrosinase inhibitor in hyperpigmentation therapy.

\section{Acknowledgment}

None.

\section{Declaration of interest}

The authors declare no competing interests

\section{Author contributions}

IMAY and NKNC conceptualized the study design, IMAY and MAWS investigated the data, IMAY, MAWS, NKNC, and NKDPD wrote original draft, IMAY, MAWS, NKDPD reviewed and edited final version. All authors have read the final manuscript.

Received: 16 December 2021

Accepted: 7 January 2022

Published online: 17 January 2022

\section{References}

1. Jablonski NG, Chaplin G. Colloquium paper: human skin pigmentation as an adaptation to UV radiation. Proc Natl Acad Sci USA. 2010;107 Suppl 2: 8962-8968. https://doi. org/10.1073/pnas.0914628107

2. Chang T-S. Natural Melanogenesis Inhibitors Acting Through the Down-Regulation of Tyrosinase Activity. materials. 2012;5: 1661-1685. https://doi.org/10.3390/ ma5091661

3. Woolery-Lloyd H, Kammer JN. Treatment of hyperpigmentation. Semin Cutan Med Surg. 2011;30: 171-175. https://doi.org/10.1016/j.sder.2011.06.004

4. Naser W. The cosmetic effects of various natural biofunctional ingredients against skin aging: a review. Int J App Pharm. 2021; 10-18. https://doi.org/10.22159/ ijap.2021v13i1.39806

5. Laksmiani NPL, Nugraha IPW. Depigmentation Activity of Secang (Caesalpinia Sappan L.) Extract Through Tyrosinase, Tyrosinase Related Protein-1 and Dopachrome Tautomerase Inhibition. Biomed Pharmacol J. 2019;12: 799-808. https://doi.org/10.13005/bpj/1703

6. Kiattisin $\mathrm{K}$, Intasai N, Nitthikan N, Nantarat T, Lee K-H, Lin $\mathrm{W}-\mathrm{C}$, et al. Antioxidant, Anti-tyrosinase, Anti-aging Potentials and Safety of Arabica Coffee Cherry Extract. Chiang Mai Journal of Science. 2019;46: 930-945.

7. Li H-R, Habasi M, Xie L-Z, Aisa HA. Effect of chlorogenic acid on melanogenesis of B16 melanoma cells. Molecules. 2014;19: 12940-12948. https://doi.org/10.3390/ molecules190912940

8. Sim J, Lanka S, Jo J-W, Chaudhary CL, Vishwanath $\mathrm{M}$, Jung $\mathrm{C}-\mathrm{H}$, et al. Inhibitory Effect of Chlorogenic Acid Analogues Comprising Pyridine and Pyrimidine on a-MSH-Stimulated Melanogenesis and Stability of Acyl Analogues in Methanol. Pharmaceuticals (Basel). 2021;14. https://doi.org/10.3390/ph14111176

9. Jo H, Zhou Y, Viji M, Choi M, Lim JY, Sim J, et al. Synthesis, biological evaluation, and metabolic stability of chlorogenic acid derivatives possessing thiazole as potent inhibitors of a-MSH-stimulated melanogenesis. Bioorg Med Chem Lett. 2017;27: 4854-4857. https://doi. org/10.1016/j.bmcl.2017.09.044

10. Lai X, Wichers HJ, Soler-Lopez M, Dijkstra BW. Structure of human tyrosinase related protein 1 reveals a binuclear zinc active site important for melanogenesis. Angew Chem Int Ed Engl. 2017;56: 9812-9815. https://doi.org/10.1002/ anie. 201704616

11. Jain AN, Nicholls A. Recommendations for evaluation of computational methods. J Comput Aided Mol Des. 2008;22: 133-139. https://doi.org/10.1007/s10822-0089196-5

12. Jung HJ, Noh SG, Park Y, Kang D, Chun P, Chung $\mathrm{HY}$, et al. In vitro and in silico insights into tyrosinase inhibitors with (E)-benzylidene-1-indanone derivatives. Comput Struct Biotechnol J. 2019;17: 1255-1264. https:// doi.org/10.1016/j.csbj.2019.07.017 
13. Pannindriya P, Safithri M, Tarman K. Analisis In Silico Senyawa Aktif Sprirulina platensis sebagai Inhibitor Tirosinase. Jurnal PHPI. 2021;24: 70-77. https://doi. org/10.17844/jphpi.v24i1.33122
14. Alam N, Yoon KN, Lee JS, Cho HJ, Lee TS. Consequence of the antioxidant activities and tyrosinase inhibitory effects of various extracts from the fruiting bodies of Pleurotus ferulae. Saudi J Biol Sci. 2012;19: 111-118. https://doi. org/10.1016/j.sjbs.2011.11.004 